\title{
The male reproductive system of Hippolyte inermis Leach 1815 (Decapoda, Caridea)
}

\author{
Vanesa Cobos • Vanessa Díaz • Jose Enrique García Raso • \\ M. E. Manjón-Cabeza
}

Received: 4 March 2009/Revised: 4 March 2010/Accepted: 16 March 2010/Published online: 8 April 2010

(C) Springer-Verlag and AWI 2010

\begin{abstract}
The present work completes a series of studies on the biology of the shrimp Hippolyte inermis Leach 1815, where we suggested the species to be gonochoristic. The morphology of the male reproductive system (testes, vasa deferentia, gonopores) and the different stages of male germ cell development are described for the first time in the genus Hippolyte, using TEM, SEM, and histological methods. All males from 1.70 to $3.42 \mathrm{~mm}$ in carapace length had active testes and well-developed vasa deferentia. No case of sex reversal could be found.
\end{abstract}

Keywords Go · Hermaphroditism - Hippolyte inermis . Zostera $\cdot$ Caridea

\section{Introduction}

Protandry is common among species that belong to the Hippolytidae (Dohrn 1950; Noël 1976; Nakashima 1987; Gherardi and Calloni 1993; Fielder 1998; Simoes et al. 1998) and other caridean families, e.g., Pandalidae (Jägersten 1936; Mistakidis 1957; Allen 1959; Butler 1964; Berreur-Bonnenfant and Charniaux-Cotton 1965; Hoffman 1972; Charnov 1981), Crangonidae (Spitschakoff 1912; Fréchette et al. 1970; Boddeke et al. 1991).

Communicated by H.-D. Franke.

V. Cobos · V. Díaz · J. E. G. Raso · M. E. Manjón-Cabeza $(\square)$ Department of Animal Biology. Faculty of Science, Málaga University, Campus de Teatinos, s/n., 29071 Málaga, Spain

e-mail: mecloute@uma.es
Published data about the reproductive biology of Hippolyte inermis Leach 1815 support the idea that this species is a protandric hermaphrodite (Zupo 1994, 2000) and males would undergo a sex reversal more or less controlled by environmental factors (Zupo 2000; Nappo et al. 2006; Zupo et al. 2007). However, two different studies from our laboratory have found no evidence for hermaphroditic sexuality in adult specimens of this species after a careful examination of the morphology of the reproductive structures (Cobos et al. 2005) and an exhaustive study of its population structure and absolute growth (Manjón-Cabeza et al. 2009). Recent studies regarding the reproductive system in other species of Hippolyte have not found either any cases of sex reversal (Espinoza-Fuenzalida et al. 2008; Terossi et al. 2008), and consequently they were described as gonochoristic species.

The main purpose of the present work, which completes a series of studies on the biology of $H$. inermis, is to highlight those aspects related to the morphology of the testis (with a special emphasis on some interesting features concerning the orientation of spermatozoa) and the vas deferens.

\section{Materials and methods}

Sampling

During the years 2000 and 2001, monthly samples (total $=12$ ) were taken from meadows of the seagrass, Zostera marina (Linnaeus), at El Cañuelo Bay $\left(36^{\circ} 44^{\prime} 40.5^{\prime \prime} \mathrm{N}\right.$, $\left.03^{\circ} 47^{\prime} 56.3^{\prime \prime} \mathrm{W}-36^{\circ} 44^{\prime} 23.2^{\prime \prime} \mathrm{N}, \quad 03^{\circ} 47^{\prime} 22.7^{\prime \prime} \mathrm{W}\right)$. Mediterranean Sea, Málaga, Spain). A dredge $(76.6 \times 30 \mathrm{~cm}$, with a net of $3 \times 3 \mathrm{~mm}$ from knot to knot) was towed for $10 \mathrm{~min}$ (total sampled area: $235 \mathrm{~m}^{2}$ ). 
In the laboratory, the leaves of $Z$. marina and the sediment were washed, and specimens of $H$. inermis were separated and fixed in different fixatives depending on the histological technique used. The sex of individuals was inferred from the morphology of the first pleopod and presence of the male appendage on the second pleopod. For this study, 176 males were measured, dissected, and histologically examined.

\section{Dissection}

Using a stereomicroscope, the cuticle, muscles, and different organs that conceal the ovaries and oviducts (mostly near the female gonopores in the coxa of the third pereopod) of an individual shrimp were removed using small scissors and sharp tungsten needles. The reproductive system anatomy could then be compared with that of other carideans.

\section{Microscopy}

\section{SEM}

Samples were fixed in $1 \%$ glutaraldehyde and $1 \%$ paraformaldehyde diluted in phosphate buffer saline (PBS) and postfixed in $1 \% \mathrm{OsO}_{4}$ in $\mathrm{PBS}$. For paraffin sections, the samples were dehydrated in an ethanol series finishing in butanol, paraffin embedded, and sectioned with Leica (Hatfield, PA, USA) microtome blades (model 819) using a Leitz (Germany) microtome. After obtaining the desired profile, the wax was removed with xylene. All structures and paraffin sections were washed several times in $100 \%$ ethanol, and critical-point dried using ethanol as the transitional fluid and $\mathrm{CO}_{2}$ as the exchange fluid. Dried specimens were sputter-coated with gold (450 ̊) Observations were made using a Jeol (Tokyo, Japan) JSM-840 scanning electron microscope.

\section{TEM}

Samples were fixed and postfixed as described above. Specimens were dehydrated in an ethanol series, boiled by acetone, and embedded in araldite (Fluka 502) Semithin and ultrathin sections $(1,0.1 \mu \mathrm{m})$ were obtained with an Ultracut E Reichert-Jung ultramicrotome. Semithin sections were stained with $1 \%$ toluidine blue in distilled water ( $1 \mathrm{~g}$ toluidine blue $11 \mathrm{~g}$ sodium tetraborate 10 hidrate and $1,100 \mathrm{ml}$ distilled water) and photographed with a Nikon Coolpix 990 camera adapted to the Nikon microscope. Ultrathin sections were contrasted with lead citrate and uranyl acetate, observed, and photographed with the Jeol Jem-100 CX transmission electron microscope.

\section{Histology}

Specimens were fixed in a methanol-acetone-distilled water solution $(2: 2: 1)$ for $8-12 \mathrm{~h}$ or in $4 \%$ formaldehyde, dehydrated in an ethanol series followed by butanol, and embedded in paraffin. Serial sections were obtained using a Leitz microtome and collected on poly-L-lysine-coated slides. Sections were dewaxed in xylene, hydrated in an ethanolic series, washed in distilled water, and stained with Mallory's trichrome (Pauley 1967), VOF (light green + orange $\mathrm{G}+$ acid Fucsin) (Gutiérrez 1967), PAS (periodic acid-Schiff) (Kiernan 1990), and Resorcine-Fuchsine (McManus and Mowry 1986).

\section{Results}

The reproductive system of $H$. inermis males consists of two testes that are associated with two vas deferens openings at the terminal gonopores found on the coxae of the 5th pair of pereopods (Fig. 1a). Testes are located on the dorsal side of cephalothorax, just below the heart (Fig. 1a), and extend from the anterior third of the carapace to first abdominal segment when the adult is fully active (Fig. 1b). They are covered by a thin and monolayered epithelium with flattened nuclei. This epithelium does not line different internal compartments or lobes (Fig. 1c, d).

The smallest male analyzed $(C L=1.7 \mathrm{~mm})$ possessed active testes, and its vasa deferentia were filled with spermatophores at different stages of maturation. In larger sizes (the largest one has a $\mathrm{CL}=3.42 \mathrm{~mm}$ ), it is also possible to find testes without a clear line of cell differentiation, presenting only the last stages of spermatozoa maturation. In these specimens, no primary ovary or buds have been found. Non-reproductive testes have never been found.

The differentiation line (or germinative zone) of the testes presents an obvious gradient from the inner to the outer line of both lobes (Fig. 1c, d). Hence, testes consist of different cells types, which form an epithelial germinal zone that adheres to the testicular wall and represents a stock cell population or primary-spermatogonias (Fig. 2a, b). Two phases in the maturation of testes have been recognized, spermatogenesis and spermiogenesis, as well as four cell types, which could be distinguished by their cytological features.

\section{Spermatogenesis}

Spermatogonia are often round or elliptic in shape and have a high cytoplasmatic: nucleus ratio (Fig. 2a). They are usually located forming a thin layer on the internal side of the lobes (Fig. 2b). The primary spermatocytes $\left(\mathrm{Sp}_{1}\right.$; 


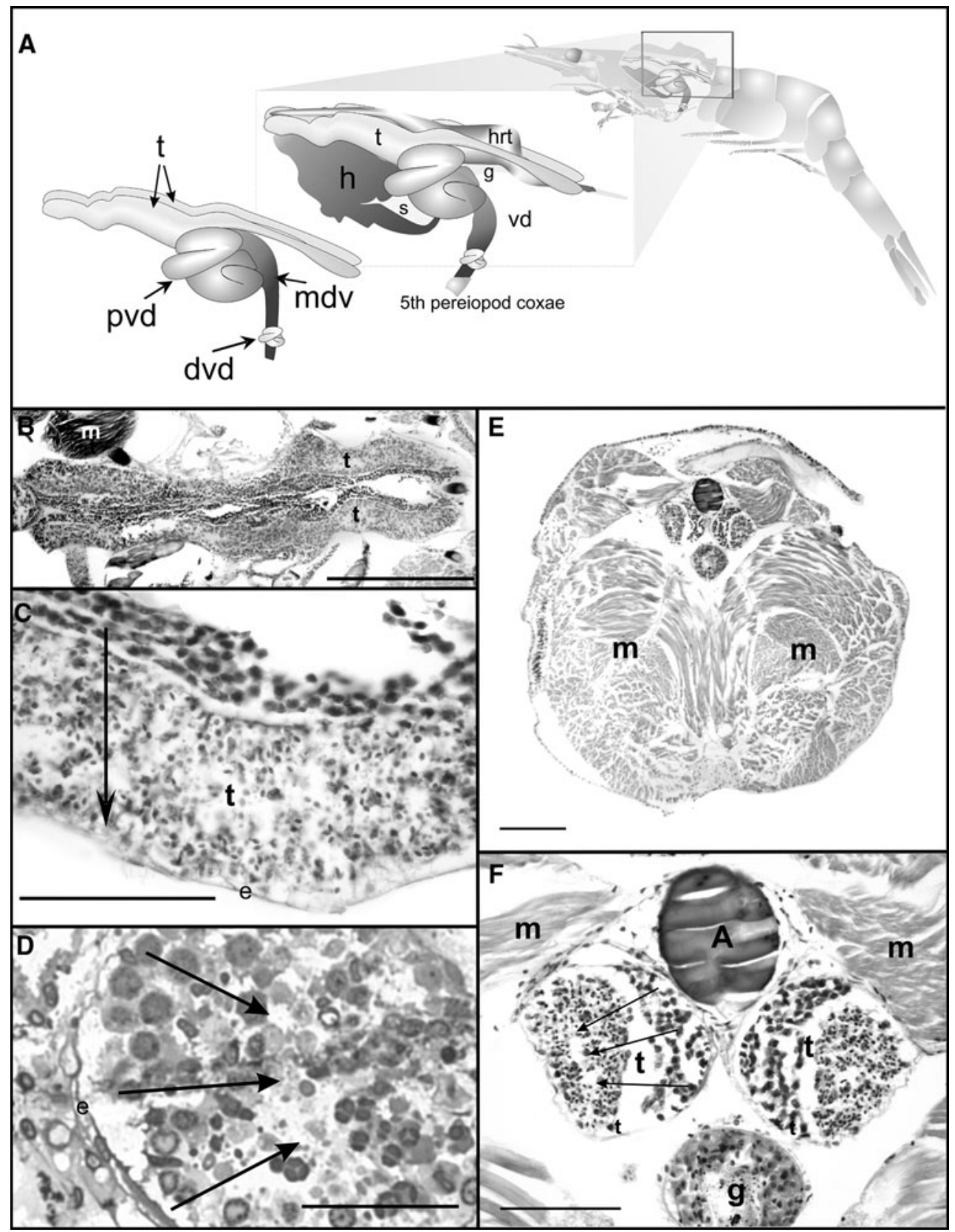

Fig. 1 Teste a diagram of male reproductive system and its different structures, their morphology, and location. b Frontal section of the testes. Mallory's trichrome stain. Scale bar, $500 \mu \mathrm{m}$. c Frontal section of the testes. Mallory's trichrome stain. Detail of the differentiation line. Scale bar, $250 \mu \mathrm{m}$. d Transverse semithin section of the posterior lobes of testes. Toluidine stain. Scale bar, $80 \mu \mathrm{m}$.

Fig. 2b, c) are the consequence of different spermatogonial divisions, which are often visible in metaphase stage. Secondary spermatocytes $\left(\mathrm{Sp}_{2}\right)$ (Fig. $\left.2 \mathrm{~b}, \mathrm{~d}\right)$ have large and central nuclei with a few heterochromatic areas in their nucleus, which grow in size, filling the whole nucleus at the end of the process of spermatogenesis. e Transversal section of the carapace of male. VOF stain. Scale bar, $250 \mu \mathrm{m}$. f Detail from e. Scale bar, $125 \mu \mathrm{m}$. A dorsal abdominal artery, arrow differentiation line, $d v d$ distal vas deferens, $e$ epithelium, $g$ gut, $h$ hepatopancreas, $h r t$ heart, $m$ muscle, $m v d$ median vas deferens, $p v d$ proximal vas deferens, $s$ stomach; $t$ teste

Spermiogenesis

It is characterized by an increment of spermatids (Spd) (Fig. 2b, e, f). At this moment, the spermatids undergo a double nuclear division, finally showing a complex nuclear area formed by four associated nuclei, forming a tetrad, 
Fig. 2 Spermatozoa

differentiation. a Spermatogonia diagram. b Transverse semithin section of the posterior lobes of testes. Toluidine blue stain. Scale bar, $40 \mu \mathrm{m}$. c Diagram and TEM microphotograph of primary spermatocytes. Scale bar, $2 \mu \mathrm{m}$. d Diagram and TEM microphotograph of secondary spermatocytes. Scale bar, $2 \mu \mathrm{m}$. e Diagram and TEM microphotograph of first spermatid. Scale bar, $2 \mu \mathrm{m}$. f Different views of spermatid tetrad and TEM

microphotograph of one inmature spermatozoa. Scale bar, $2 \mu \mathrm{m}$. g Diagram and TEM microphotograph of spermatozoa. Scale bar, $2 \mu \mathrm{m}$. h SEM microphotograph of spermatozoa. Scale bar, $1 \mu \mathrm{m}$. Sptg spermatogonia, $S p_{1}$ spermatocyte type $1, S p_{2}$ spermatocyte type 2, Spd spermatid, Spdt spermatid tetrad, Spz spermatozoa

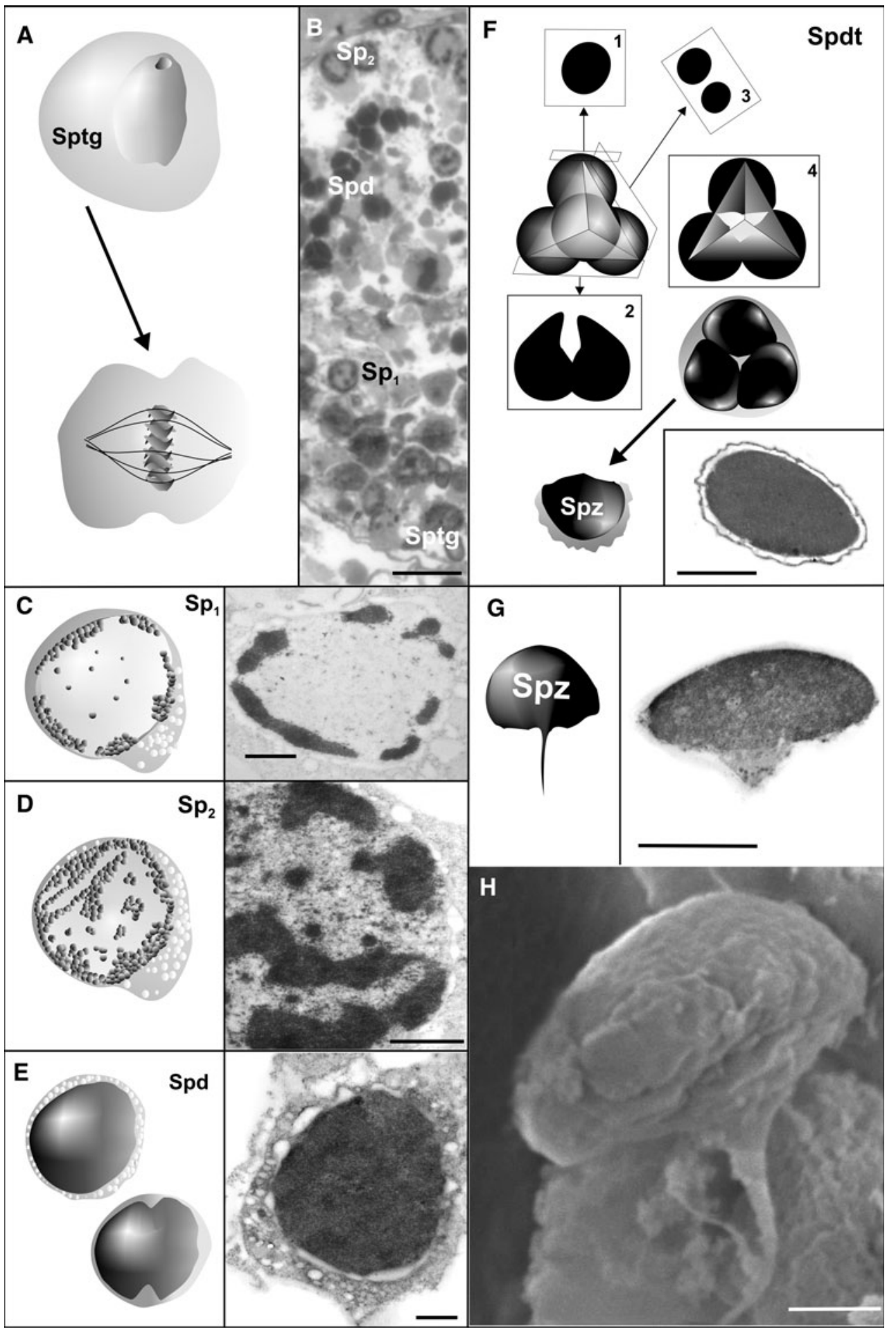

i.e., arranged as a tetrahedron (Fig. 2f). Subsequently, the tetrahedron breaks, and each nucleus surrounded by a portion of the cytoplasm is separated from the other one forming four immature spermatozoa.

Finally, the spermatozoa mature and a long spike develops, so that a new cellular organization appears, resembling a small umbrella (Fig. $2 \mathrm{~g}$, h). In addition to this main structure, another cell type, which seems to be somatic as a nutritive cell, is also found.

The deferentia vasa are very large and partially coiled (Fig. 3a). They can be divided into three zones according to their anatomy and location: proximal (Fig. 3b, c), medial (Fig. 3d, e), and distal (Fig. 3f-k). Their morphology is that of a tube with a secretory epithelium and surrounded 
Fig. 3 Vas deferens. a Diagram of vas deferens. b Frontal section of the proximal vas deferens (first coil) PAS stain. Scale bar, $200 \mu \mathrm{m}$. c Sagital section of the proximal vas deferens (second coil)

Resorcine-Fuchsine stain. Scale bar, $50 \mu \mathrm{m}$. d SEM microphotograph of paraffincarved sections of the medial vas deferens. Scale bar, $120 \mu \mathrm{m}$. e Sagital semithin section of the medial vas deferens. Toluidine stain. Scale bar, $100 \mu \mathrm{m}$. f Frontal section (only one coil) of distal vas deferens. Resorcine-Fuchsine stain. Scale bar, $20 \mu \mathrm{m}$. g Detail from E. Scale bar, $10 \mu \mathrm{m}$. h Frontal semithin section of the distal vas deferens. Toluidine stain. Scale bar, $50 \mu \mathrm{m}$. i Transverse semithin section of the distal vas deferens, near to gonopore. Toluidine stain. Scale bar, $100 \mu \mathrm{m}$. j Sagital section of the distal vas deferens near to gonopore. Mallory's trichrome stain. Scale bar, $100 \mu \mathrm{m}$. $\mathbf{k}$ Detail from J. Scale bar, $20 \mu \mathrm{m}$. ag androgenic gland, arrowheads spermatozoa, $c t$ cuticle, $d v d$ distal vas deferens, $e$ epithelium, $f$ folder, $f b$ fibrilar layer, $g$ gut, go gonopore, 1 th $h$ first coil, 2 th $h$ second coil, $m$ muscle, $m l$ muscular layer; $m v d$ median vas deferens, $p v d$ proximal vas deferens, $s_{1}$ protein substance, $s_{2}$ mucous substance, $t$ teste

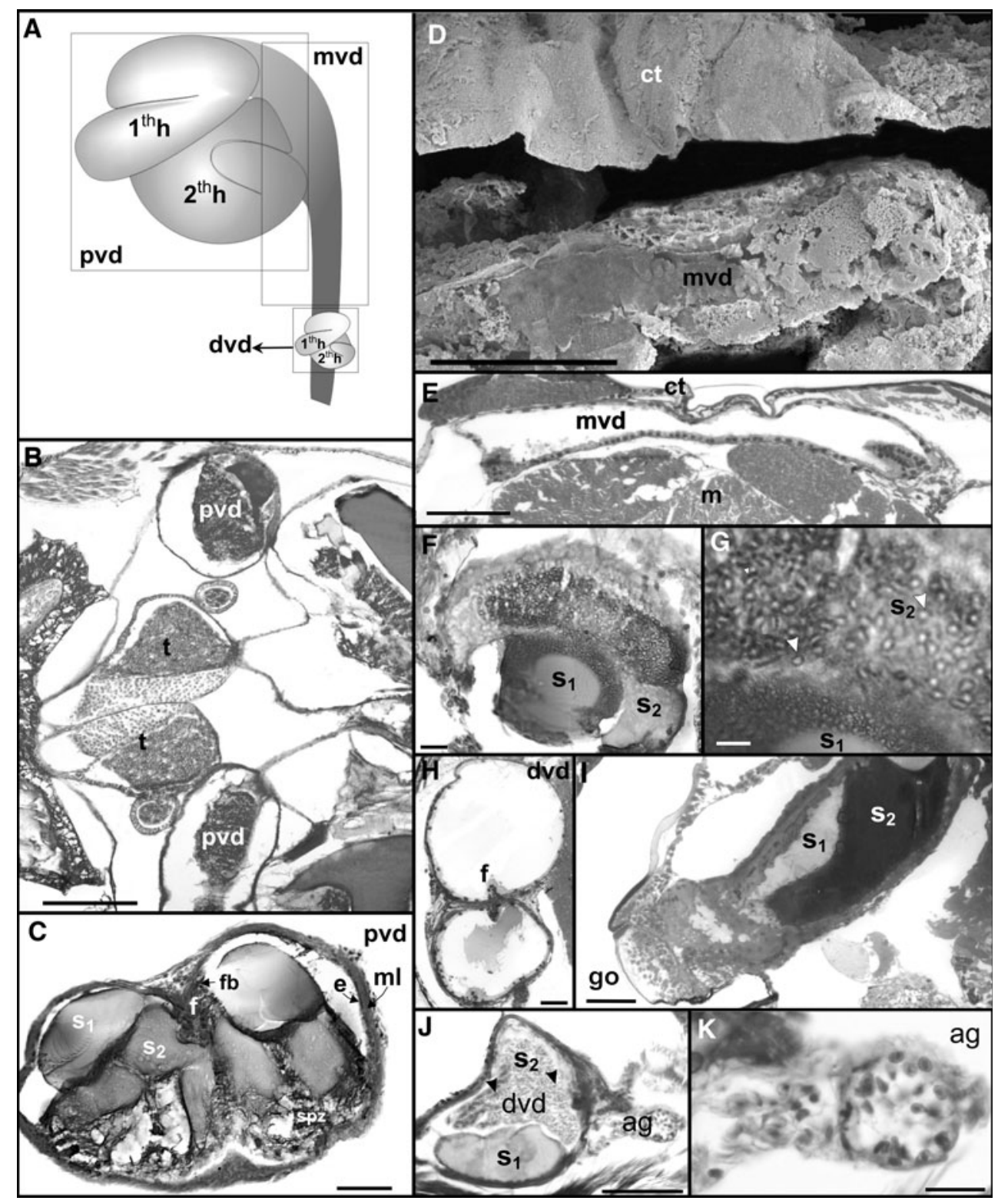

by a muscular and fibrilar layer that is thinner in the distal than in the proximal vas (Fig. 3c). There are two folds of the epithelium on opposite sides of the lumen along the entire vas.

The proximal vas deferens (pvd) is coiled over itself and consists of a cubic epithelium surrounded by a slim muscular layer. In this area, spermatozoa are mixed with two kinds of substances that display a yellow-orange color $\left(\mathrm{s}_{1}\right)$ and blue $\left(\mathrm{s}_{2}\right)$ when Mallory's stain is used (Fig. 3c, f, g, i, j). The blue substance, the matrix in which the spermatozoa are embedded, seems to be constituted of mucous components. On the other hand, the orange substance could be a proteinaceous structural matrix.

The medial vas deferens (mvd) (Fig. 3d, e) is more or less straight. The two substances described above seem to increase within the vas. A mix of mucous and mature spermatozoa is located on the lateral side of the vas, whereas the proteins are always found internally.

The distal vas deferens (dvd) (Fig. 3f-j) is coiled again, and in its final section the proteins completely surround the mix of mucous and spermatozoa. In this area, the androgenic gland was found in every male processed (Fig. 3j, k).

Finally, the vasa open through the gonopores in the coxae of the fifth pereopods (Fig. 3i).

\section{Discussion}

The described morphology for the reproductive system of $H$. inermis is found to be similar to other caridean 
gonochoristic species, as well as penaeids (Bell and Lightner 1988), anomurans (Manjón-Cabeza and García Raso 2000a, b), or brachyurans (Johnson 1980) where the testes lobes have been described. A different morphology has been observed in hermaphroditic (simultaneous or protandric) species, (i.e., Charniaux-Cotton and Payen 1992; Bauer 2000; among others) because of the presence of ovotestes, oviducts, and deferentia vasa (or some remains).

Hippolyte inermis shows a process of gametogenesis similar to that of Palaemon serratus (Pennant 1777) (Papathanassiou and King 1984a, b) in which five to six stages of gametogenesis have been described. In H. inermis, five stages have been found, although in closely related species such as Palaemon adspersus Rathke 1837, more than ten stages have been described (Spitschakoff 1909). The basic problem is to identify the number of sub stages within the main stages (spermatogonia, primary spermatocyte, secondary spermatocyte, spermatids, and mature spermatozoa).

The limits between spermatogenesis and spermiogenesis are not clear because the spermatogenesis (spermatocytes differentiation) is very fast in this species. Such high rate cell division is being only visible in some species of penaeids (King 1948; Bell and Lightner 1988, among others). Therefore, these kinds of studies basically deal with the differentiation and maturation process of the spermiogenesis.

It is important to emphasize that the spermatids, in all specimens studied, are distributed in a geometric form, as a tetrahedron. In two-dimensional histology studies, it is very difficult to see the four cells, and normally only three cells are seen in the same semi-thin section (Figs. 1d, 2b). Hoffman (1972) discussed this in his study of Pandalus platyceros Brandt 1851.

Spermatozoa of natant decapods have been profusely studied in many species (Spitschakoff 1909; PochonMasson 1965, 1968, 1969; Lu 1976; Koehler 1979; Kleve et al. 1980; Lyn and Clark 1983; Papathanassiou and King 1984b; Shigekawa and Clark 1986; Griffin et al. 1988; Bauer 2000). The results of the studies of the caridean spermatozoa have shown a great variability in shape, but their pattern is generally similar to that of $H$. inermis. In our study, the spermatozoa exhibit the shape of a small umbrella due to the development of a long spike. The function of this spike seems to be involved in the fertilization of ovocites (Lynn and Clark 1983; Demestre et al. 1997; Kruevaisayawan et al. 2008).

In H. inermis, like in other carideans, ventral and dorsal epithelia vas deferens contribute two different types of substances which determine the morphology of the spermatophore (Chow et al. 1982; Chow et al. 1989) In this case, coiled portions of the tube help to increase the secretion of the two substances described above. In some cases, it is possible to observe two folds in the tube lumen, which seem to contribute to forming the two layers of the spermatophore.

The caridean spermatophore (i.e.,: palaemonids, Chow et al. (1989)) is shown to be a simpler structure than in other species, as occurs in penaeids (Demestre and Fortuno 1992) or in anomurans (Manjón-Cabeza and García Raso 2000a). It is a cylinder with two layers: one with mucous substance and spermatozoa, and another layer composed of structural substances.

Finally, these results (based on 176 males studied without any signs of sex reversal), altogether with our previous studies (Cobos et al. 2005; Manjón-Cabeza et al. 2009), support the existence of a gonochoric structure of the studied population of $H$. inermis (from Zostera beds) like has been described recently in other species of the same genus such as H. williamsi Schmitt 1924 H. obliquimanus Dana 1852 (Espinoza-Fuenzalida et al. 2008; Terossi et al. 2008).

Acknowledgments This research is supported by grant: PB97-1116 and MAR98-1706-E. "Estudio de la macrofauna de los fondos de fanerógamas marinas, Zostera y Cymodocea, del Sur de España", from Spanish M.E.C, DGICYT funds. We want to thank M.J. Martín and E. García Muñoz, Msc for assisting with the treatment of the samples as well as D. Macias PhD, D. López, PhD, and A. Guerrero, $\mathrm{PhD}$., for their help with the ultramicrotome and the photographic work. Also, we want to thank Gregorio Martin Caballero from the SEM central services of the University of Málaga for his good work. Finally, we want to thank Sandra Méneaud, English teacher of the University of Málaga and Dr. Serge Gofas for reviewing the manuscript.

\section{References}

Allen JA (1959) On biology of Pandalus borealis Kroyer, with reference to a population off the Northumberland coast. J Mar Biol Assoc UK 38:189-220

Bauer RT (2000) Simultaneous hermaphroditism in caridean shrimps: a unique and puzzling sexual system in the Decapoda. J Crust Biol 20(Special Number 2):116-128

Bell TA, Lightner DV (1988) Handbook of normal Penaeid Shrimp histology. Word Aquaculture Society, Baton Rouge

Berreur-Bonnenfant J, Charniaux-Cotton H (1965) Hermaphrodisme protérandrique et fonctionnemente de la zone germinative chez la crevette Pandalus borealis Kröyer. Bull Soc Zool Fr 90:240259

Boddeke R, Bosschieter JR, Goudswaard PC (1991) Sex change, mating, and sperm transfer in Crangon crangon (L.). In: Bauer RT, Martin JW (eds) Crustacean sexual biology. Columbia University Press, New York, pp 164-182

Butler TH (1964) Growth, reproduction and distribution of Pandalid shrimps in British Columbia. J Fish Res Board Can 21(6):14031452

Charniaux-Cotton H, Payen G (1992) Artrhropoda-Crustacea: sexual differentiation. In: Adiyodi KG, Adiyodi RG (eds) Reprocuctive biology of invertebrates $\mathrm{V}$ : sexual differentiation and behaviour. Wiley, New York, pp 281-323 
Charnov EL (1981) Sex reversal in Pandalus borealis: effect of a shrimp fishery? Mar Biol Letters 2:53-57

Chow S, Ogasawara Y, Taki Y (1982) Male reproductive system and fertilization of the palaemonid shrimp Macrobrachium rosenbergii. Bull Jap Sci Fish 48:177-183

Chow S, Taki Y, Ogasawara Y (1989) Homologous functional structure and origin of the spermatophores in six palaemonid shrimps (Decapoda, Caridea). Crustaceana 54:247-252

Cobos V, Diaz V, García Raso JE, Manjón-Cabeza ME (2005) Insights on the female reproductive system in Hippolyte inermis (Decapoda, Caridea): is this species really hermaphroditic? Invertebr Biol 128:310-320

Demestre M, Fortuno JM (1992) Reproduction of the deep-water: Aristeus antennatus (Decapoda, Dendrobranchiata). Mar Ecol Prog Ser 84:41-51

Demestre M, Cortadellas N, Durfort M (1997) Ultrastructure of the Sperm of the Deep-Sea Decapod: Aristeus antennatus. J Morphol 234:79-87

Dohrn PFR (1950) Studi sulla Lysmata seticaudata Risso (Hippolytidae) I Le condidicioni normali della sessualita in natura. Pubbl Stn Zool Napoli 22:257-272

Espinoza-Fuenzalida NL, Thiel M, Dupre EJ, Baeza A (2008) Is Hippolyte williamsi gonochoric or hermaphroditic? a multiapproach study and a review of sexual systems in Hippolyte shrimps. Mar Biol 155:623-635

Fielder GC (1998) Functional, simultaneous hermaphroditism in female/phase of Lysmata amboinensis (Decapoda: Caridea: Hippolytidae). Pac Sci 52:161-169

Fréchette JG, Corrivault GW, Couture R (1970) Hermaphroditisme protérandrique chez une crevette de la famille des crangonidés, Argis dentata Rathbun. Nat Can 97:805-822

Gherardi F, Calloni C (1993) Protandrous hermaphroditism in the tropical shrimp Athanas indicus (Decapoda: Caridea), a symbiont of sea urchins. J Crust Biol 13:675-689

Griffin FJ, Shigekawa K, Clark WH (1988) Formation and structure of the acrosomal filament in the sperm of Sicyonia ingentis. J Exp Zool 246:94-102

Gutiérrez M (1967) Coloración histológica para ovarios de peces, crustáceos y moluscos. Inv Pesq 31(2):265-271

Hoffman DL (1972) The development of the ovotestes and copulatory organs in a population of protandric shrimp, Pandalus platyceros Brandt from Lopez Sound, Washington. Biol Bull 142:251-270

Jägersten G (1936) Über die Geslechtsverhältnisse und das Wachustum bei Pandalus. Arkiv för zoologi 28:26

Johnson PT (1980) Histology of the Blue crab, Callinectes sapidus: a model for the Decapoda. Praeger, New York

Kiernan JA (1990) Histological and histochemical methods: theory and practice. Pergamon Press, plc, Oxford, p 433

King JE (1948) A study of the reproductive organs of the common marine shrimp, Penaeus setiferus (Linnaeus). Biol Bull 94:244262

Kleve MG, Yudin AI, Clark WH (1980) Fine structure of the unistellate sperm of the shrimp, Sicyonia ingentis (Natantia). Tissue Cell 12:29-45

Koehler LD (1979) A unique case of cytodifferentiation: spermiogenesis of the prawn, Palaemonetes paludosus. J Ultrastruct Res 69:109-120

Kruevaisayawan H, Vanichviriyakit R, Weerachatyanukul W, Iamsaard S, Withyachumnarnkul B, Basak A, Tanphaichitr N, Prasert Sobhon P (2008) Induction of the acrosome reaction in black tiger shrimp (Penaeus monodon) requires sperm trypsinlike enzyme activity. Biol Reprod 79:134-141

Lu CC (1976) Studies of the testicular tissue and spermatogenesis in the brown shrimp Penaeus aztecus (Decapoda)- PhD. Thesis. University of Houston
Lynn JW, Clark WH (1983) The fine structure of the mature sperm of the freshwater prawn, Macrobrachium rosenbergii. Biol Bull 164:459-470

Manjón-Cabeza ME, García Raso JE (2000a) Morphological reproductive aspects of males of Diogenes pugilator (Roux, 1829) (Crustacea: Decapoda: Anomura) from Souther Spain. Sarsia 85:195-202

Manjón-Cabeza ME, García Raso JE (2000b) Reproductive aspects of females of the hermit crab Diogenes pugilator (Crustacea: Decapoda: Anomura) from southern Spain. J Mar Biol Assoc UK 80:85-93

Manjón-Cabeza ME, Cobos V, García Muñoz JE, García Raso JE (2009) Structure and absolute growth of a population of Hippolyte inermis Leach 1815 (Decapoda Caridea) from Zostera marina (L.) meadows (Malaga, southern Spain). Sci Mar 73(2):377-386

McManus JFA, Mowry RW (1986) Técnica histológica. Ed. Ática, Madrid

Mistakidis MN (1957) The biology of Pandalus montagui Leach. Fish Inv London 21(2):52

Nakashima Y (1987) Reproductive strategies in partially protandrous shrimp, Athanas kominatoensis (Decapoda: Alpheidae): sex change as the best of a bad situation for subordinates. J Ethol 5:145-159

Nappo M, Avila C, Taboada S, Batiga J, Codina C, Segi A, Aflalo ED, Manor M, Weil S, Ventura T, Zupo S, Volta C, Messina P, Raniello R, Zupo V (2006) Towards the characterization of a new apoptotic factor from marine benthic diatom Cocconeis scutellum. XIV Simposio Ibérico de Estudios de Biología Marina, Barcelona

Noël P (1976) L'évolution des caractères sexuels chez Processa edulis Risso (Décapode, Natantia). Vie Milieu 25(1, sér. A): 65-104

Papathanassiou E, King PE (1984a) Ultrastructural studies on gametogenesis of the prawn Palaemon serratus (Pennant) I. Oogenesis. Acta Zool (Stockh) 65(1):17-31

Papathanassiou E, King PE (1984b) Ultrastructural studies on gametogenesis of the prawn Palaemon serratus (Pennant) II. Spermiogenesis. Acta Zool (Stockh) 65(1):33-40

Pauley GB (1967) A modification of Mallory's aniline blue collagen stain for oyster tissue. J Invertebr Pathol 9:268-269

Pochon-Masson J (1965) Schéma général du spermatozoïde vésiculaire des Décapodes. CR Accad Sci, Paris 260:5093-5095

Pochon-Masson J (1968) L'ultraestructura des spermatozoïdes vésiculaires chez les Crustacés Décapodes avant et au cours de leur dévagination expérimentale I. Brachyures et Anomures. An Sci Nat Zool 12:1-100

Pochon-Masson J (1969) Infrastructure du spermatozoïde de Palaemon elegans (Crustacé: Décapode). Arch Zool Exp gén 110:363-372

Shigekawa K, Clark WH (1986) Spermiogenesis in the marine shrimp, Sicyonia ingentis. Dev Growth Differ 28:95-112

Simoes F, Yasir I, Jones DA (1998) Reproductive biology of Lysmata deberlius (Bruce, 1983) and L. amboinensis (De Man, 1888), (Crustacea: Caridea) tropical marine cleaner shrimps important in the sea water aquarium trade. Abstract. World Aquaculture Society. Las Vegas, p 3

Spitschakoff TH (1909) Spermien und spermiohistogenese bei Cariden. Arch Zellforscha 3:1-43

Spitschakoff TH (1912) Lysmata seticaudata Risso, als Beispiel eines echten Hermaphroditismus bei den Decapoden. Z Wiss Zool 100:109-209

Terossi M, López Greco LS, Mantelatto FL (2008) Hippolyte obliquimanus (Decapoda: Caridea: Hippolytidae) a gonochoric or hermaphroditic shrimp species? Mar Biol 154:127-135 
Zupo V (1994) Strategies of sexual inversion in Hippolyte inermis Leach (Crustacea, Decapoda) from a Mediterranean seagrass meadow. J Exp Mar Biol Ecol 178:131-145

Zupo V (2000) Effect of microalgal food on the sex reversal of Hippolyte inermis (Crustacea: Decapoda). Mar Ecol Prog Ser 201:251-259
Zupo V, Messina P, Buttino I, Sagi A, Avila C, Nappo C, Bastida J, Codina Zupo S (2007) Do benthic and planktonic diatoms produce equivalent effects in crustaceans? Mar Freshwater Behav Physiol 40:169-181 